\title{
Integrating carbon isotope excursions into automated stratigraphic correlation: an example from the Silurian of Baltica
}

\author{
PETER M. SADLER
}

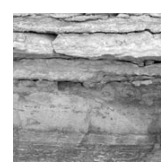

\begin{abstract}
To correlate the burgeoning volume of biostratigraphic information available from the Silurian rocks of Baltica, it is advantageous to use numerical algorithms. Graphical correlation and related numerical methods routinely incorporate taxon range-ends and bentonites. Bentonites must be matched exactly. Local taxon ranges match or under-represent true ranges and may be stretched to fit hypotheses of correlation. Carbon isotope excursions are better handled as conservative uncertainty intervals - a new data class with properties and freedoms that are the opposite of taxon ranges. Uncertainty intervals match or over-represent truly correlative segments and inflexion points in the local series of isotopic ratios; they may be shrunk to fit correlations between sections. By these means, three fundamentally different kinds of stratigraphic information may be combined in a mutually supportive fashion without over-stating the precision of any of them. When incorporated as uncertainty intervals, Silurian isotopic excursions improve automated construction of inter-regional, ordinal time-lines of taxon first- and last-appearances at both the coarsest and finest resolution. The known succession of a few named excursions helps to stack relatively brief stratigraphic sections into their correct order in longer time-lines. The limits and details of individual excursions support some of the highest-resolution segments of optimized time-lines of individual taxon originations and extinctions. At intermediate scales, local taxon ranges are the unrivalled information source. For the best results, detailed taxon ranges, bentonite analyses and stable isotope time series need to be developed from the same rocks as often as possible. - Key words: biostratigraphy, chemostratigraphy, bentonite, graphic correlation, constrained optimization, Silurian, Baltica.
\end{abstract}

SADLER, P.M. 2012. Integrating carbon isotope excursions into automated stratigraphic correlation: an example from the Silurian of Baltica. Bulletin of Geosciences 87(4), 681-694 (9 figures, appendix). Czech Geological Survey, Prague. ISSN 1214-1119. Manuscript received July 31, 2011; accepted in revised form January 10, 2012; published online May 16, 2012; issued October 17, 2012.

Peter Sadler, Department of Earth Sciences, University of California, Riverside, CA 91521; peter.sadler@ucr.edu

Progressive refinement of the Silurian stratigraphic framework for Baltica has reached a challenging threshold: the growing volume of relevant stratigraphic information threatens to overwhelm traditional correlation methods that rely solely upon expert human inspection of faunal lists and two-dimensional graphs. Stratigraphic sections continue to be published from sea cliffs, quarries and numerous well cores (Fig. 1) that preserve the local ranges of biostratigraphically useful fossil clades. My current compilation of readily available literature contains local ranges for nearly 800 Silurian graptolite, conodont, chitinozoan and acritarch taxa (exclusive of cf. and sp. identifications) from 82 sections. This surely underestimates the information held by experts: Rubel et al. (2006) built a composite chitinozoan range chart from 44 Baltic localities, whereas my compilation includes chitinozoan data for only fourteen. In addition to taxon ranges, there are local records of more than 50 recognized K-bentonite beds and at least three carbon isotope excursions. All this information amounts to more than 6,600 local records of events (taxon range ends, excursion peaks, etc.) to be considered in correlation. The majority are local taxon range ends which, inevitably, differ in the details of their sequence from place to place.

Decades ago, biostratigraphers in petroleum companies faced the same challenge - too much information to manage mentally but not enough to point straightforwardly to the true sequence of taxon origination and extinction events. To build a composite sequence from its large biostratigraphic database and to resolve the innumerable local contradictions in the preserved sequence of events, AMOCO adopted Shaw's (1964) graphic correlation technique (Mann \& Lane 1995, Shaw 1995). Graphic correlation remains popular for Palaeozoic biochronology (e.g. Grubb \& Finney 1995, Gouwy \& Bultynck 2003, Sweet 2005, Rubel et al. 2006, Kleffner \& Barrick 2011). Although manual graphic correlation becomes impractically 


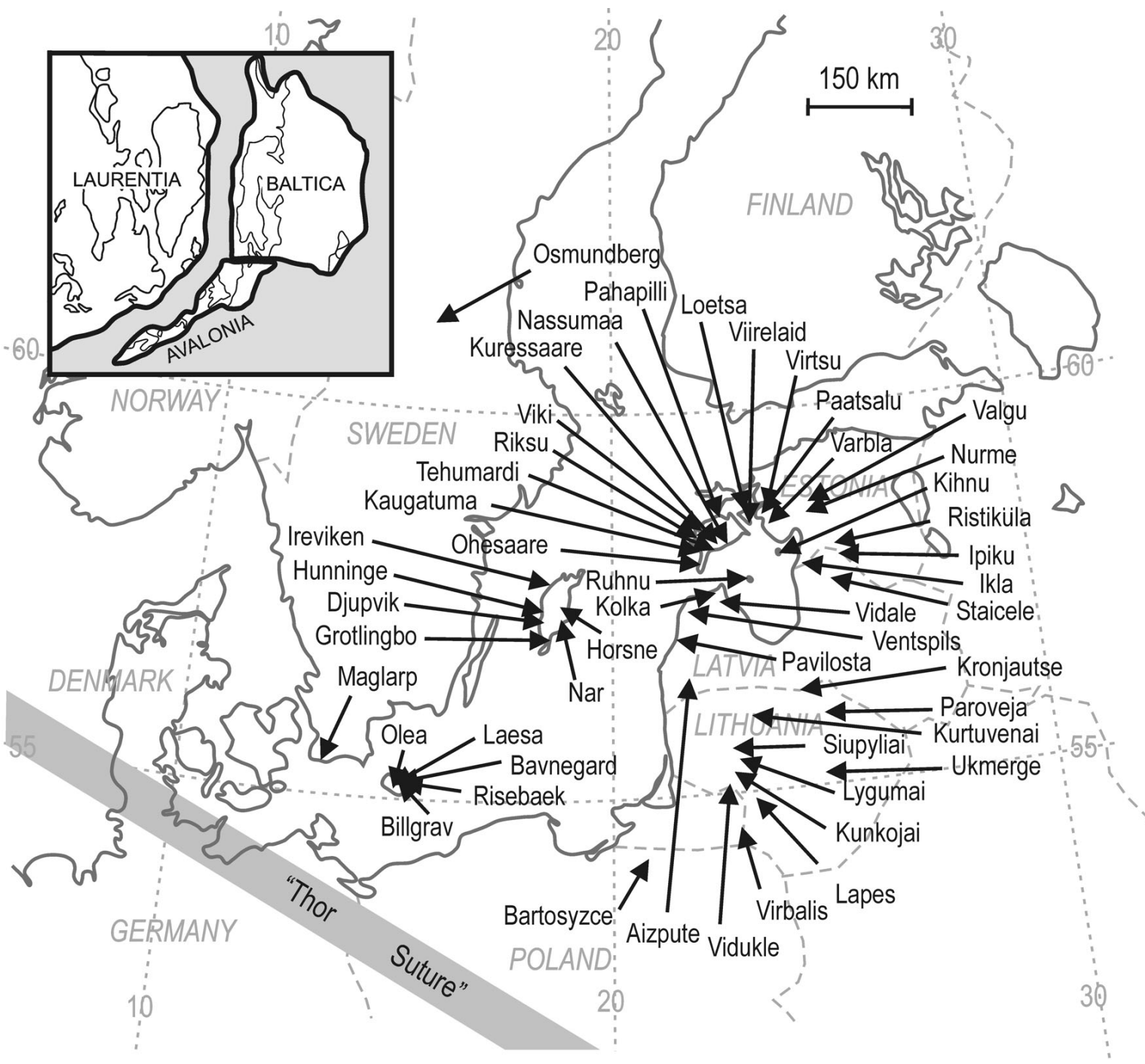

Figure 1. Location of many of the cores and sections in the rich stratigraphic record of Silurian rocks of Baltica, shown on present day map coordinates. Inset: early Silurian palaeogeography.

tedious for very large volumes of data, computer programs have taken over the data handling aspects. An alternative computer technique for sequencing large amounts of firstand last-appearance data is constrained optimization (CONOP; Sadler et al. 2003; latest freeware version obtainable from the author); the CONOP program builds directly upon Shaw's concept of "economy of fit" to perform a multidimensional graphic correlation (Kemple et al. 1995; Sadler 2004, 2010). CONOP has been used to sequence Neogene diatoms (Cody et al. 2008), the entire graptoloid clade (Sadler \& Cooper 2011), late Ordovician chitinozoans (Hints et al. 2011), Ordovician conodonts (Goldman et al. 2011) and the Permo-Triassic mass extinction (Shen et al. 2011).

Graphic correlation was designed to deal with taxon range-ends and readily incorporates marker beds, such as geochemically fingerprinted K-bentonites, that can be confidently matched from place to place. Carbon isotope excursions differ significantly from these two kinds of information. After a brief review of graphic correlation and "economy of fit" to illustrate how CONOP optimizes the fitness of palaeobiological time-lines, I shall contrast the essential properties of three classes of time-stratigraphic information, describe a means to include isotope excursions in CONOP, and illustrate some benefits that result.

\section{Graphic correlation and CONOP}

The foundation of Shaw's graphic correlation is an x-y scatter plot: the axes of the plot are two stratigraphic sections; 
each youngs away from the origin; and the line of correlation (LOC) that connects the $(\mathrm{x}, \mathrm{y})$ coordinates of coeval horizons must have non-negative slope everywhere on the graph. Events preserved in both sections plot as points on the graph (Fig. 2) and guide placement of the LOC. Depending upon the nature of the events and their preservation, the LOC may be constrained to pass through a point or simply to pass as near as possible to as many points as possible. It is the essence of biostratigraphic correlation problems that LOCs of non-negative slope can almost never be arranged to pass though all points at the coordinates of shared taxon range-ends. Instead, some points (as few as possible) must be adjusted (as little as possible) to fall on a plausible LOC.

The patchy, dynamic nature of biotic communities and the vagaries of preservation combine to leave local records of taxon range that underestimate true ranges by unknown amounts. The amounts surely vary from place to place and from taxon to taxon. Thus, local time-lines of appearances and disappearances of fossil taxa vary as a result of both real ecologic differences and incomplete preservation and sampling. Compensation for the underestimation is achieved by limiting the adjustments of points on the graph to those that extend observed ranges. Minimizing the total amount of adjustment is an exercise in optimization, which Shaw (1964) called "economy of fit" (Kemple et al. 1995). It is more exactly termed constrained optimization because the scope of permissible adjustments is restricted.

LOCs resolve differences between two sections and fix a sequence of events to which both may be fit. CONOP uses a multiple-section LOC as the composite sequence of events. LOCs also allow information from one section to be projected into another. Shaw's graphic correlation uses such projections to progress from individual sections to a composite section via a succession of these two-section plots. Graphic correlation is an iterative process that adds sections, one-by one, to the growing composite. Then several rounds of refinement are needed to remove bias introduced by the order in which sections were added. Refer to Shaw (1964) or Mann \& Lane (1995) for full details. For the purpose of understanding how CONOP proceeds, it is not necessary to examine the logic of the later iterations in graphic correlation. Two-section plots are used here simply to illustrate the concept economy of fit between local data and hypothetical sequences of events by analogy with linear regression (MacLeod \& Sadler 1995). Although economy of fit is common to both graphic correlation and CONOP, the purpose of the LOC is different in a subtle but operationally significant way.

In graphic correlation one section on the succession of two-section graphs is always assumed, a priori, to be the better. On the initial graph it is a subjective choice that becomes the composite section, which is carried forward as an emerging solution, from one 2-section plot to the next.

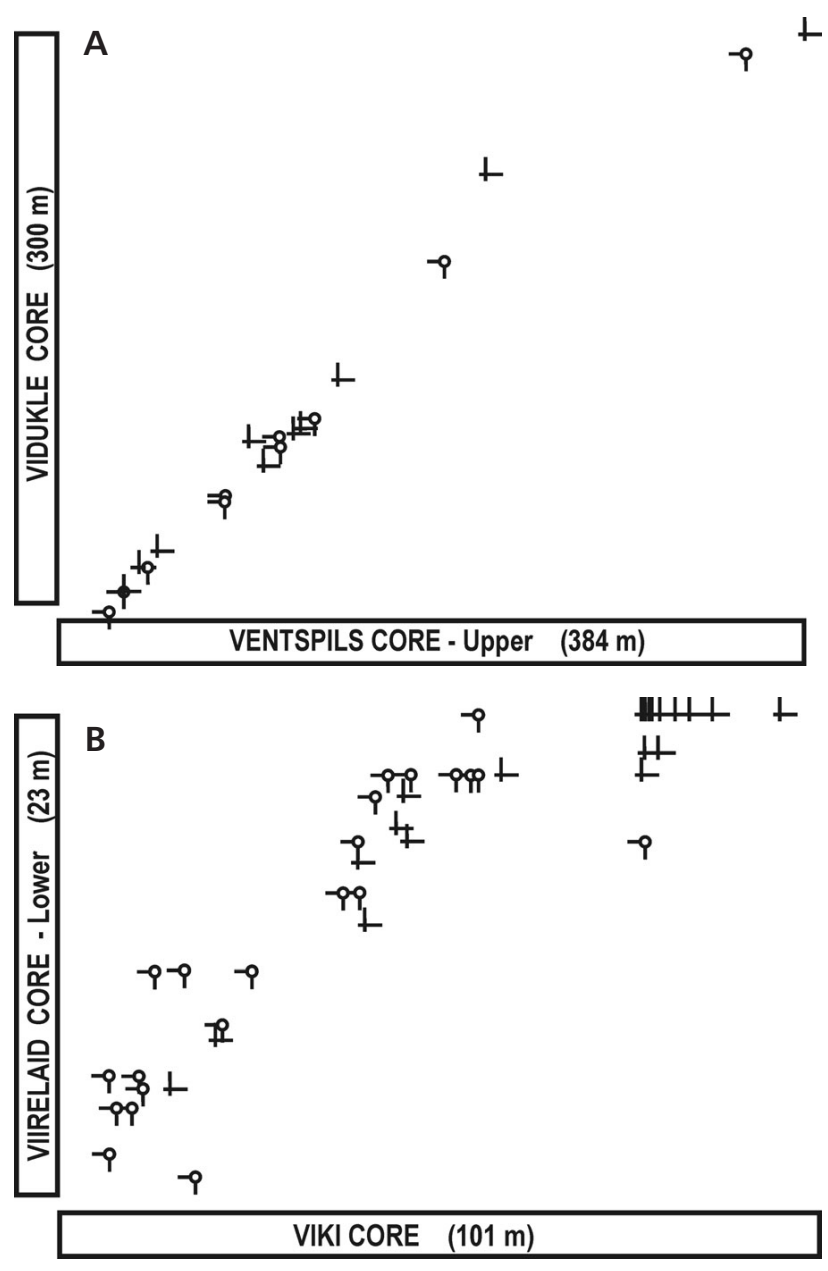

Figure 2. Graphic representation of pairs of Baltic Silurian cores using shared taxon range-end coordinates to indicate best-fit line of correlation (LOC). • A - LOC constrained to a narrow path. • B - LOC less well constrained. Angle symbols with circles for first-appearance range-ends point down and to left; longer arms of cross symbols for last-appearance range-ends point up and to right. The long ends of both symbols indicate directions in which coordinates may be adjusted to stretch observed range; i.e. first-appearances down-section only; last appearances up-section only. The $\mathrm{x}$ - and $\mathrm{y}$-axes are not drawn to the same scale.

Only adjustments that enhance the composite section are of interest. The best placement of the LOC for this purpose attempts to keep the coordinates of first- and last-appearances on opposite sides of the LOC (MacLeod \& Sadler 1995). To facilitate this process, first- and last- appearances are traditionally plotted as circles and crosses, respectively.

For CONOP, by contrast, a multi-section LOC is the solution, not a composite section. CONOP manages a single "graph" with one dimension for every section. All sections are considered at once. There need be no a priori preferred section. The computer tracks adjustments to all sections. Therefore, CONOP adjusts all points onto the LOC, in effect, examining the consequences of fitting all sections to the same sequence of events in a piecewise 


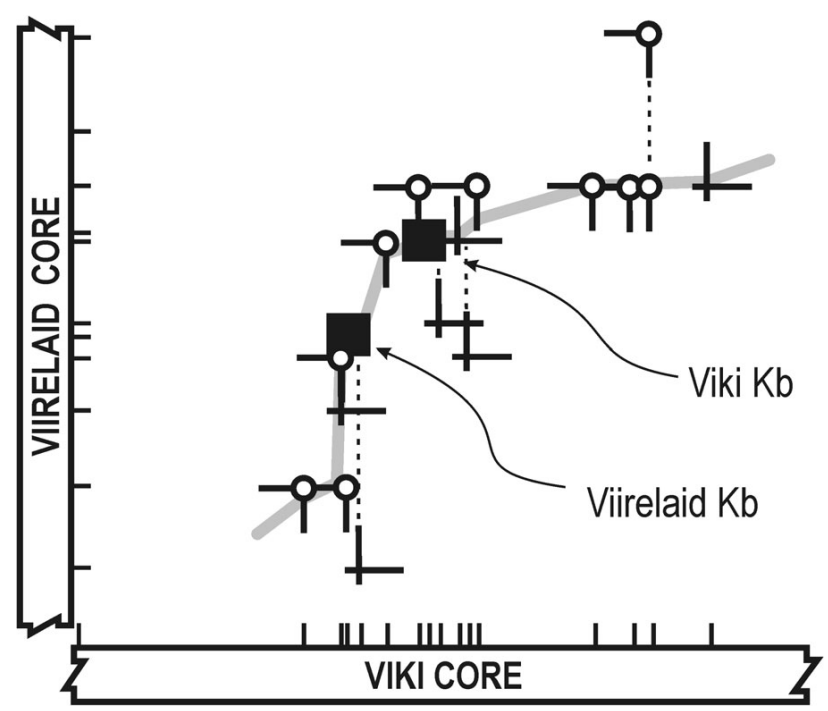

Figure 3. Two-dimensional projection of detail of best-fit, 82-section, ordinal, CONOP time-line for sections in a portion of Fig. 2B. Matched bentonites (filled squares) constrain choice of sequence of range end coordinates (angle symbols as in Fig. 2). Ticks on the core axes indicate the number and position of observed event horizons. Dashed lines indicate range extensions needed to fit all range-end events to the time-line (thick grey line).

linear regression. To facilitate this process it is a CONOP convention to plot range-end events as right angle symbols whose open ends point in the directions of permitted adjustment; i.e. range extensions in either section (Fig. 2). To accommodate readers with either CONOP or graphic correlation experience, the right angle symbols are combined with smaller crosses and circles in this paper.

Of course, the CONOP multi-section "graph" is actually a set of matrices, with one column for every section and rows for stratigraphic events. In place of experts drawing a succession of LOCs, the algorithms may be imagined to manipulate the order of the rows to find an optimal fit. CONOP capitalizes on the computer's facility for tedious iterative tasks. Its matrix manipulations use all information from all sections throughout the optimization process. CONOP algorithms achieve this by inverting Shaw's process (Kemple et al. 1995). Instead of building a solution progressively from the data, the algorithms test a huge set of possible solutions against all of the data. Starting from an essentially random guess, the algorithms improve the solution by mutation and fitness tests, much like organic evolution (Kemple et al. 1995). Solutions are possible sequences of all events; they are palaeobiological time-lines. The terms LOC and time-line will be used to differentiate between graphic correlation and CONOP, respectively.

The choice between graphic correlation and CONOP is a trade-off between mutually exclusive advantages. Graphic correlation favors the transparency of correlation on two-section graphs. CONOP sacrifices transparency for the advantage of a total data approach, which also eliminates some apparent subjectivity and gains reproducibility (Kemple et al. 1995).

Graphic correlation adjusts ranges on the unique continuous thickness scale of the standard section which records the sequence and spacing of events. The resulting spacing is strongly influenced by the accumulation history of the standard section. CONOP initially optimizes timelines only for the order of events. It adjusts range-ends in all sections, but only to other event horizons. The resulting multi-section time-line is purely ordinal and does not represent the spacing of events. Two-section projections of the multi-section ordinal time-line resemble LOCs but differ in this regard: the ordinal time-line is subsequently scaled using thickness information from all sections and then calibrated using dated events (Sadler et al. 2009).

This three-step process (sequencing-spacing-calibrating) minimizes bias introduced by local differences in accumulation rate. The bias can be further reduced by minimizing the size of local range adjustments as measured in numbers of event levels rather than a thickness scale. Carbon isotope excursions require special consideration only in the first of the three steps and that is the focus of this paper.

\section{Three specific types of information for correlation}

Time-stratigraphic correlation for the Silurian of Baltica rests primarily on three kinds of information: the local stratigraphic positions of bentonite beds, taxon range-ends, and carbon isotope excursions. Stratigraphic fidelity varies considerably between these three and they must be handled differently in correlation.

\section{Ash-fall bentonites}

In the Silurian deposits of Baltica, chemically fingerprinted bentonites are the best candidates for time-stratigraphic marker horizons. Their deposition time is much briefer than the general resolving power of geologic correlation or calibration. They are the simplest, most effective and most demanding of time-stratigraphic information. Their stratigraphic positions are assumed to be faithfully recorded. In graphic correlation they fix points whose coordinates may not be adjusted to the LOC; rather, the LOC must pass through them (Fig. 3); that is, other events must be adjusted to honor the a-priori assumption that the bentonite horizons correlate precisely. Accordingly there must be strong evidence that the same bentonite is identified in each location. 


\section{Taxon ranges}

The use of taxon ranges in correlation relies upon the uniqueness of species. Every fossil taxon adds two unique events to the time-line - its origination and extinction. It is highly unlikely that local first- and last-appearances will correspond exactly with true origination and extinction events (FADs and LADs). The local observed ranges are almost inevitably too short and may be stretched until all sections fit the same LOC or time-line (Figs 3, 4). In other words, local first-appearances may be adjusted downward only and the local last-appearances upward only.

Because a FAD may not be adjusted upward, it cannot change position relative to LADs and bentonites seen above it in any section. A corresponding constraint holds for LADs and bentonites found below them. These observations may stem from a single section and yet exercise powerful constraints on LOCs and timelines. They are sufficient to drive Alroy's (1994) appearance event ordination algorithms and the unitary association method (Guex 1991), two other approaches to automated correlation. These constraints place an obvious premium on consistent taxonomy. The resulting composite range will encompass not only all local occurrences of a species, but also any local variations in the species concept.

\section{Carbon isotope excursions}

Continuous, high-resolution, stable-isotope records developed from Neogene and younger sediment cores may be correlated by sophisticated time-series software and automated graphic correlation (e.g. Lisiecki \& Raymo 2005). Numerous correlative cores prove the stability of the result. Silurian chemostratigraphy faces bigger challenges: sections tend to be shorter (relative to the interval between fluctuations in isotope ratios); the sampling interval may be greater; the likelihood of post depositional compromise is much higher; and the opportunities for independent age calibration are fewer. Carbon isotope correlation in the Silurian depends upon a small number of striking positive excursions that have been recognized in strata of essentially the same age from widely separated locations (Cramer et al. 2011a). In addition to this empirical justification for correlating carbon isotope excursions, ocean circulation and mixing dynamics provide physical reasons to expect comparable timing over wide areas.

Like taxa, Silurian carbon isotope excursions have been named and correlated, but they differ from fossil taxon ranges in significant ways. Fossil species may be identified and named in isolation. An isotope excursion may be recognized as such in isolation but cannot be assigned a name without associated evidence of approximate age. More significantly, the end of a taxon range is the difference

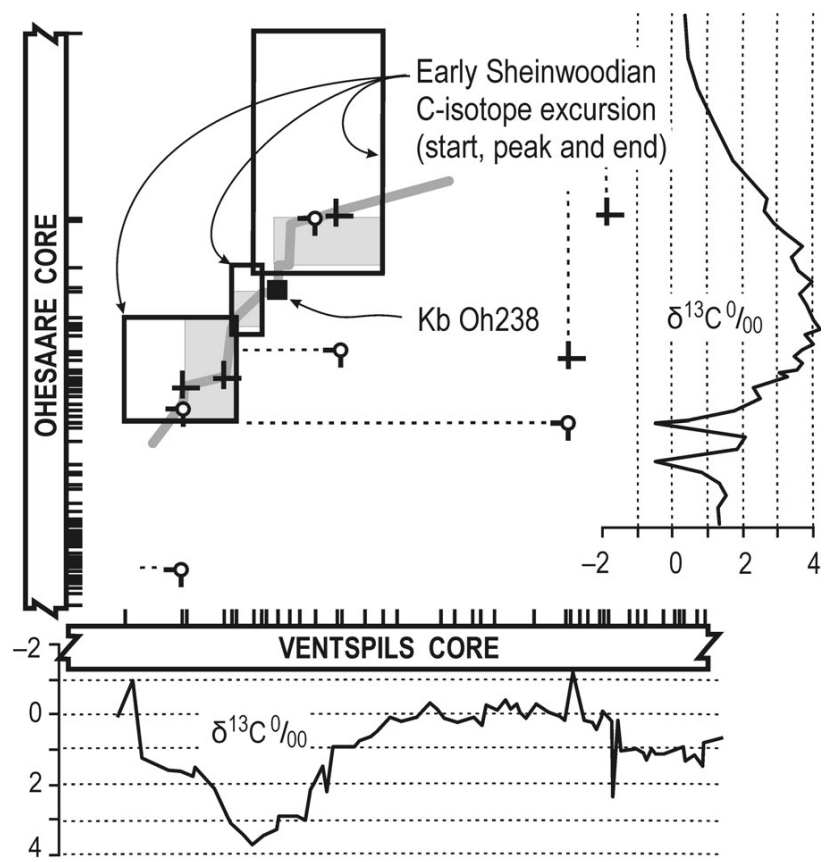

Figure 4. Two-dimensional projection of detail of a best-fit, 82-section, ordinal, CONOP time-line (thick grey line) constrained by a bentonite marker bed and uncertainty intervals on the early Sheinwoodian carbon isotope excursion. Large open rectangles: one possible representation of excursion as uncertainty intervals before shrinkage to fit information from all 82 sections. Grey rectangles: shrunk by CONOP time-line optimization. Ticks on the core axes indicate the number and position of observed event horizons, most of them recording range-end events not shared by the two sections. Isotope curves from Kaljo \& Martma (2006).

between presence and absence of the fossil taxon; this distinction and local recognition of a range end is self-evident, even if absence may be a misleading artifact of preservation. Isotopic excursions are delimited by finite changes between successive values in a stratigraphically ordered series of isotope analyses. There is no useful chemostratigraphic equivalent of absence. Positive excursions are readily recognized qualitatively where values rise substantially to one or more peaks and then subside. Cramer et al. (2010) recognized the beginning of an excursion by the rate of change of delta values, but there is no standard numerical method for picking boundaries and peaks of Silurian isotope excursions and no standardized procedure for distinguishing excursions from random fluctuations in sparsely sampled sections. The form and clarity of an excursion is influenced by sample spacing, the material analyzed, and differences in the post depositional history of samples. Even where these factors are constant, the appearance of an excursion can be influenced by the distribution of hiatal surfaces and changes in accumulation rate. Parts of an excursion may be truncated at the limits of a sampled section.

For automated correlation of Silurian excursions, therefore, it seems prudent to place conservative uncertainty 
intervals separately on various parts of each anomaly; e.g. the rising and falling sections, as well as the peaks or plateaus. Intervals may overlap one another and multiple peaks may be recognized within a plateau of high values. Not all sampled sections need to differentiate all the segments of an excursion. Local patterns should be neither over- nor under-interpreted. Uncertainty will be greatest where sampling is sparse or the form of the excursion either complex or indistinct. The goal is to ensure that all uncertainty intervals assigned to the same part of the same excursion, but in different sections, include at least one point of the same age. Thus, the interval assigned to a rising section, for example, needs to start conservatively in a sampled level with near background isotope values and to extend one or two samples beyond the peak value or the older edge of high plateau values. An essential part of the exercise is to imagine the possible impact on correlation of new samples with higher or lower values between those actually available.

Unlike local taxon ranges that stretch to fit time-lines, uncertainty intervals shrink to fit; i.e. the older limit of uncertainty may be adjusted up-section only and the younger limit down-section. In graphic correlation these uncertainty intervals define rectangular boxes that the LOC must intersect somewhere (Fig. 4). If the LOC does not pass along the main diagonal, the box shrinks to fit; the LOC becomes the main diagonal of the new box and the amount of shrinkage in each section is a measure of misfit to be minimized in a manner equivalent to the extension of a taxon range. Stretching of taxon ranges may be boundless; shrinkage of uncertainty intervals must stop when the limits meet each other and the box becomes a point. LOCs and time-lines will only depart from the main diagonal of the local uncertainty box if the placement of other events demands it or would require greater net adjustment of other observations.

Because they shrink to fit, rather than stretch, uncertainty intervals can enforce greater constraint on LOCs and time-lines than individual taxon ranges - even the ranges of those taxa that serve to identify named isotopic excursions. The degree of constraint will vary along LOCs and time lines. Both tend to be best constrained and most reliable in the vicinity of bentonites or brief isotope excursions that generate small uncertainty boxes (Fig. 5). Tighter uncertainty boxes enforce more constraint and very small boxes are operationally indistinguishable from bentonite marker beds; i.e. they have more power to trammel the time-line and force taxon range extensions. Tight local uncertainty intervals, based upon intensive sampling in sections with a rich record of fossil taxa and/or bentonites, will drive the shrinkage of larger uncertainty intervals in other sections with a rich fossil record but sparse isotopic analyses. Of course, all local uncertainty intervals must be loose enough to ensure that they contain a valid correlation. Taxon range ends may stretch to fit any sequence! If isotopic excursions are named out of order relative to one another or to bentonite correlations, however, there will be no viable time-line; CONOP algorithms will report a partial-ordering error.

In deciding how large an uncertainty interval needs to be, one needs to realize that even very loose intervals may assist considerably in the assembly of composite time-lines that span much more time than individual sections. Shaw's method was designed for correlation in the strict sense; i.e. compositing sections that all overlap considerably in time. Reconstructing Silurian macroevolutionary dynamics is more a matter of "seriation;" i.e. the desired time-line is a stack of much shorter sections many pairs of which could not generate a useful $x-y$ plot because they do not overlap in time. Graphic correlation must either start with the section of longest duration, regardless of its completeness, or stitch together several composites by other means. By inverting the process and starting from a complete but largely random time-line, CONOP avoids this snag entirely. Nevertheless, the trial-and-error process of optimizing the stack of events in the time line is considerably accelerated if many sections can immediately be placed into the coarse temporal framework of a series of major isotopic excursions. Both graphic correlation and CONOP struggle to correlate between biotic provinces that share few taxa (Sadler \& Sabado 2009). Isotope excursions may be traced across province boundaries. Thus, although the full value of Silurian isotopic excursions to time stratigraphy derives from tight geochemical sampling in richly fossiliferous sections (Cramer et al. 2010), the ability to place loose uncertainty intervals on less favorable sections has considerable value for assembling time-lines for dissimilar biotas that differ in age or province.

\section{Generalizing to other forms of information}

Although numerous types of events may be applied to correlation, they correspond to a smaller number of logical classes according to the adjustments that may be made when fitting time-lines (Sadler \& Cervato 2011). The preceding discussion of bentonites, fossil taxa and isotopes may be resolved into three generic classes of event. The first two enjoy routine use. The third is new; it has been added to the CONOP freeware and tested for about two years.

- Correlative horizons ("ASH" events in CONOP notation) - local stratigraphic positions that may not move to fit a time-line and for which there is strong evidence that 1) the same horizon is identified in each location and 2) the horizon is not diachronous; e.g. ash-fall bentonites, turbidite beds. LOCs and time-lines simply honor the a priori assumption of correlation; in the graphic correlation idiom: the LOC must pass through the shared coordinates of these points. 
- Underestimated intervals (paired range-end events, "FAD" and "LAD" in CONOP notation) - intervals that may stretch to fit time-lines because uniquely identifiable and locally observed ends of the interval must fall at or between the ends of the true interval; e.g. taxon ranges. Parsimony demands that time-lines pass as close as possible to the shared coordinates of as many of these interval end-points as possible. LOCs and time-lines tend to report the maximum known interval.

- Overestimated intervals (paired uncertainty limit events, "MAX" and "MIN" in CONOP notation) - intervals that may shrink to fit an LOC because the local ends of the interval are conservatively placed to ensure that they encompass the true correlative interval or horizon; e.g. stable isotope excursions. Time-lines must intersect the boxes generated by the shared coordinates of the interval ends.

We may imagine interval classes that are free to migrate up-section or down-section as a unit. Stratigraphic intervals of this type provide little or no constraint for time correlation. The Silurian of Baltica includes other types of time stratigraphic information that may be fit into the three time-stratigraphically useful categories as follows.

\section{Radioisotopic dates}

Radioisotopic dates may be handled in the first or third category. Dated horizons bring the unique advantage that their relative ages are known whether or not they occur in superposition at a single locality. Thus, dated horizons of different age in different sections have a predetermined order on LOCs and in time-lines. This limits the number of feasible time-lines that need to be evaluated during optimization (Sadler 2006). A dated horizon has a known and fixed stratigraphic position that is not subject to adjustment. Although this can justify assigning a dated event to the first category, the estimated age usually carries an uncertainty. Age estimates of two dated events may overlap leaving their true order unresolved. Thus, it is better to treat dated events as overestimated intervals. In the local sections, both ends of the interval (MAX and MIN in CONOP notation) plot at the sampled horizon. They cannot be adjusted there because no more shrinkage is possible. The relative position and separation of all MAX and MIN pairs for dated events is recorded by also placing them in an additional section that has a time scale rather than a thickness scale. If age estimates from different isotopic systems need to be kept separate, there can be a time-scaled section for each system. This treatment allows dated events and their uncertainties to be included in the optimization process from the outset, avoids placing too much confidence on the mean age estimate, and permits calibration of the resulting timeline by regression, without reference to biozones.
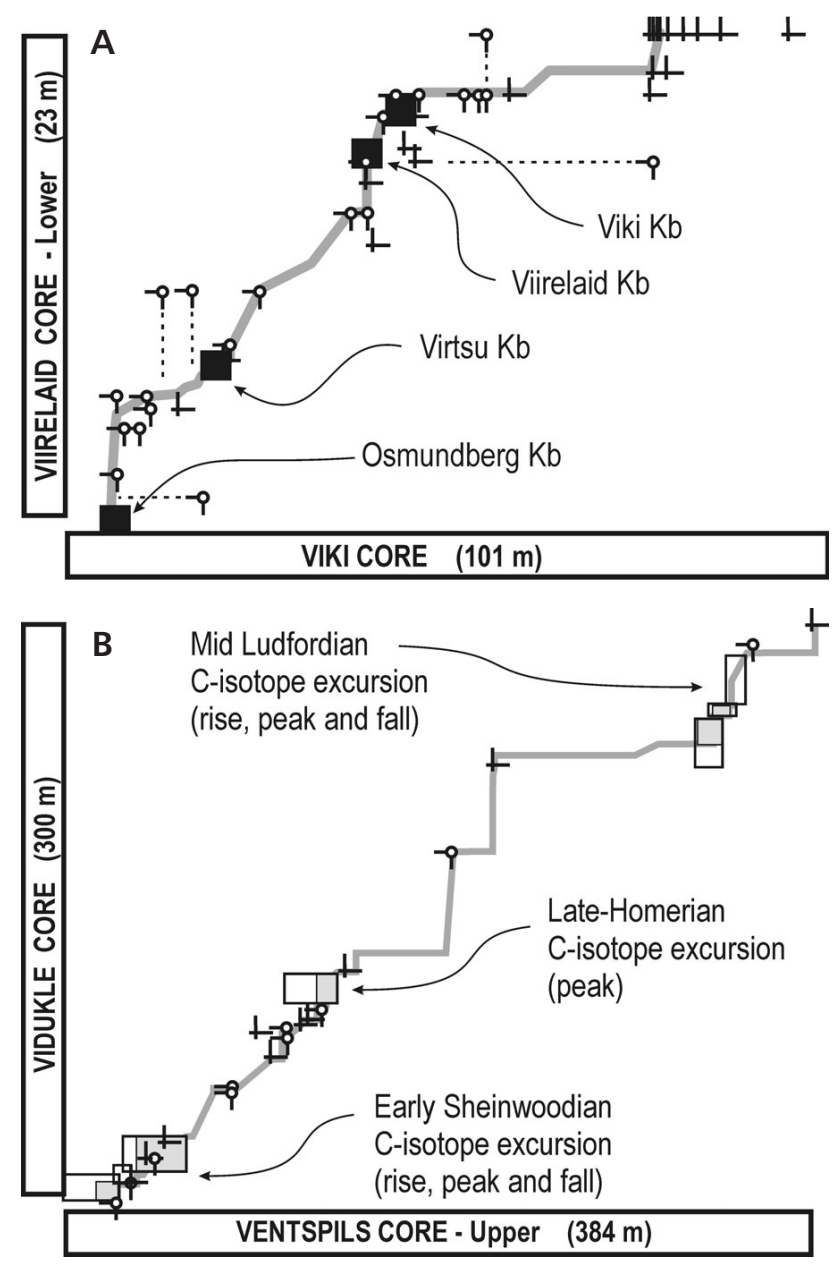

Figure 5. Best-fit ordinal, CONOP time-lines for cores in Fig. 2. - A - time-line placement constrained by bentonite marker beds within a wider swath of range-end events. - B - isotope excursions force a departure from simplest time-line through sparse taxon range ends. Uncertainty intervals fit to isotope curves in Kaljo \& Martma (2006). Grey inner rectangles, where present, indicate shrinkage from local uncertainty intervals (open rectangles) where better constraint was supplied by other stratigraphic information. The illustrated ordinal time-lines (grey) were fit by CONOP to information from 82 sections, not merely the pairs in these graphs; inflexion points without shared events are fit to events projected into the section from which they are missing.

\section{Biozone boundaries}

The contribution of chemostratigraphic sections to highresolution time-lines is compromised when they are published with individual isotopic measurements but only biozone boundaries instead of raw taxon-range data. Biozone boundaries may be used as events in numerical correlation, but should surely most often be represented as conservative uncertainty intervals. These intervals should at least span the gap between successive fossiliferous samples and at best a confidence interval based on the size frequency distribution of gaps between finds within the range of the definitive taxa. It has been assumed, since at least the advent of 


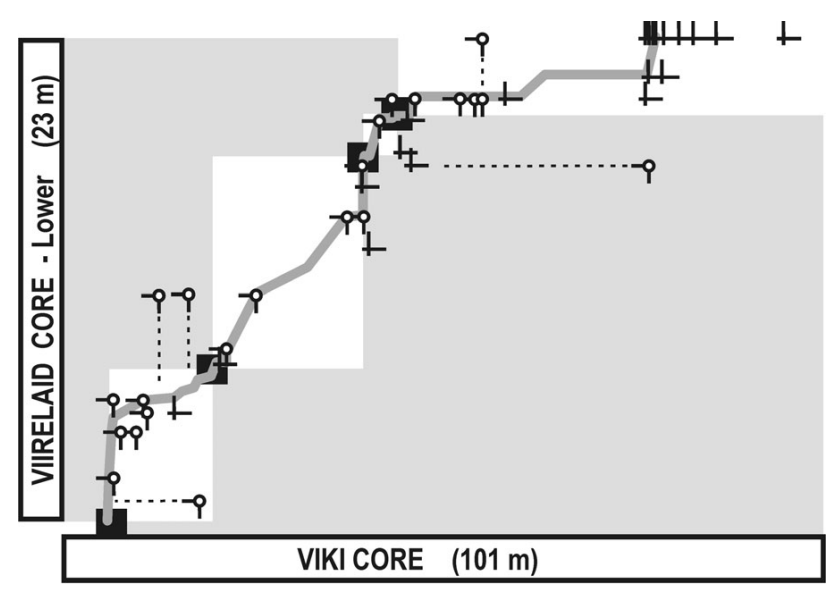

Figure 6. Shared marker beds and uncertainty intervals delineate areas of graph (grey) that are out-of-bounds to ordinal CONOP time-lines. Assuming the marker beds and uncertainty intervals are correctly matched, local range-ends that fall within grey area are surely diachronous as preserved. Other symbols as in Fig. 2.

graphic correlation, that the local first occurrences of a taxon are not precisely time correlative. Building time-lines for acritarchs alone, for example, is difficult because so many taxa are long-lived, span more time than many local stratigraphic sections, and are rather facies dependent; this task is aided considerably by including both the acritarch taxon ranges and uncertainty intervals for stage boundaries established by independent evidence. The uncertainty intervals for the stage boundaries may be placed in order on a time-scaled section.

\section{Sequence boundaries}

Careful and confident field geologists may wish to treat sequence boundaries as marker horizons, but the CONOP process cannot undo or adjust such a-priori decisions about correlative horizons. Ultimately, a robust framework of sequence boundaries would ensure very high resolving power. Where the correspondence of sequence boundaries is less certain, a stratigraphic interval encompassing several sequences may be entered as an uncertainty interval. Boundaries between Silurian stratigraphic units have been traced as seismic surfaces beneath the Baltic Sea (Tuuling \& Floden 2009). Were the seismic boundaries to be traced into cores, the vertical resolution of the seismic surfaces would likely correspond to uncertainty intervals in the cores.

\section{Acme horizons and intervals}

The recovered abundance of a taxon varies throughout its range, but the use of acme horizons as precisely correlative time-horizons has weak theoretical support. CONOP offers a looser option that constrains an acme horizon to adjustment up and down within the corresponding taxon range. If local acme intervals involving one or more taxa are identified precisely or conservatively, they might be ventured as under- or over-estimated intervals, respectively.

\section{Compromised information}

Because we have limited freedom to adjust them, marker beds and uncertainty intervals exert considerable constraint on feasible time-lines. In 2-dimensional projections of their operation, they become gateways through which time-lines must pass (Fig. 5). Because LOCs and time-lines cannot have negative slopes, these gateways act like collimators, constraining the trajectories of feasible time-lines approaching and leaving the gate; thus, each gateway renders two rectangular areas of the graph out-of-bounds to time-lines. At a bentonite, the out-of-bounds areas converge on a point (Fig. 6). Uncertainty intervals on an isotope excursion set wider gateways, but the out-of-bounds areas remain considerable. Unequal radioisotopic dates, one in each section, define a single out-of-bounds area any time-line entering the out-of-bounds quadrant would place the dated events out of order (Sadler 2006).

By contrast, range-end events may be stretched without bound to fit any sequence of events, though not without raising the magnitude of misfit between that time-line and the field data. The value of range-end events lies in the large numbers available to define an optimal "path of least adjustment" for LOCs and time-lines between gateway constraints. Range ends that plot within out-of-bounds areas must be diachronous and cannot avoid adjustment to the time-line by CONOP (in graphic correlation only those adjustments would be made that extend ranges in the composite section). All discrepancies are resolved by adjustments that stretch the composite range, whether they result from flawed taxonomy, incomplete preservation, or faunal migration. Inconsistent taxonomy tends to lengthen composite taxon ranges because it loosens de facto species definitions. Entirely mistaken identifications might equate two taxa of different age and cause whole segments of timelines to telescope, but this is unlikely unless bad data out-number the good. Telescoping can also be caused by taxa with long ranges that have been found only in short and non-correlative sections. Both risks of telescoping are greatest if the taxa concerned are the only ones that bridge between dissimilar biotic provinces. In both cases, telescoping will be prevented if an isotope excursion occupies the interval between the non-correlative ranges or partial ranges.

It can also happen that an isotope excursion defines an out-of-bounds area that encloses an immovable marker bed (Fig. 7A). Adjustments cannot resolve this situation because shrinkage enlarges the out-of-bounds areas. An error 

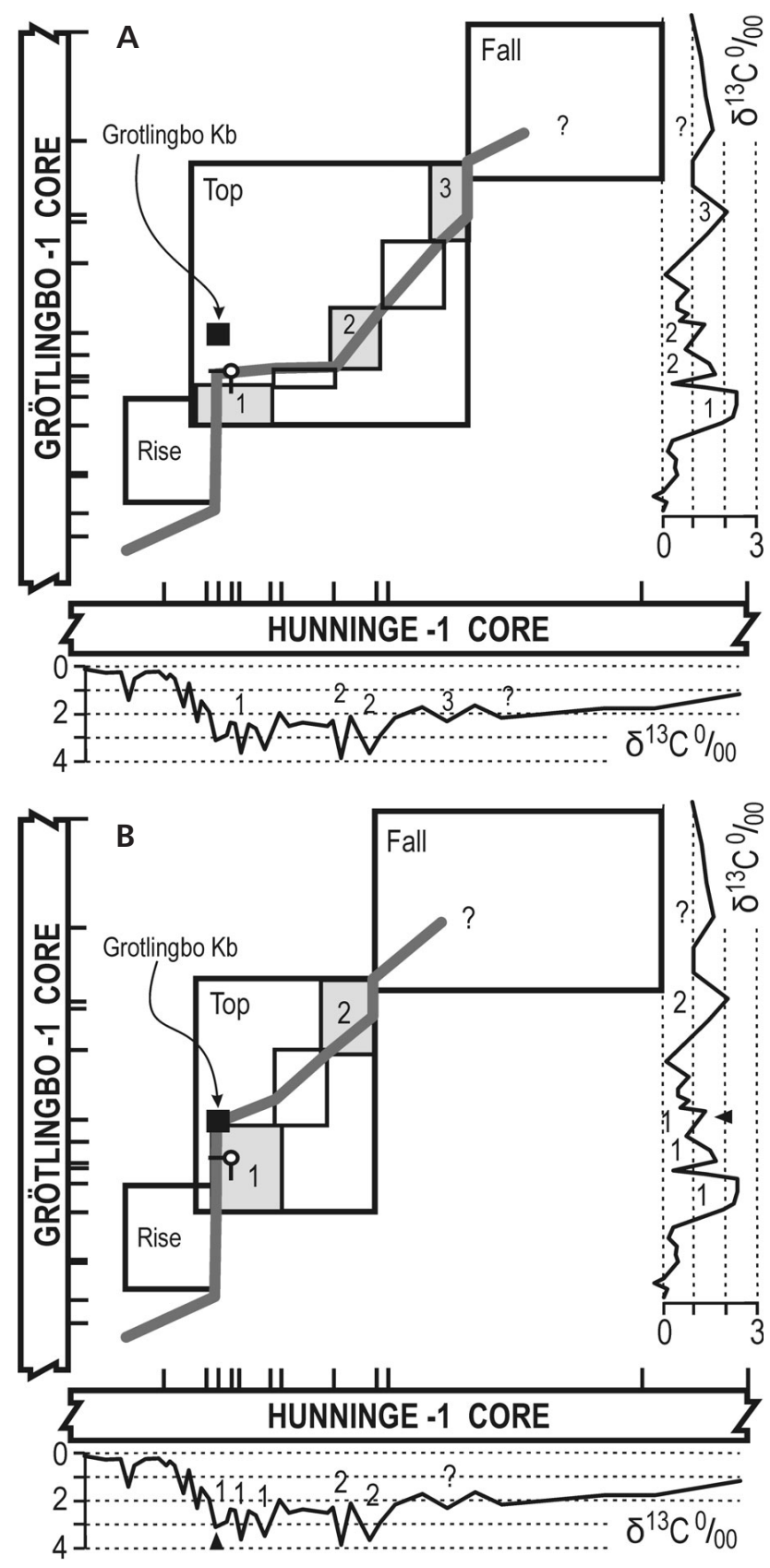

must be purged from the input data: either an uncertainty interval has been set too small, or the excursions do not match, or the marker beds are not the same. Figure 7 illustrates how such a situation might arise from attempts to eke extra resolving power from subordinate fluctuations in carbon isotope data. The example imagines trying to refine the Homerian correlation between basin (Grötlingbo-1 core) and shelf (Hunninge-1 core). The characteristic Homerian ("Mulde") excursion has a double peak. In both shelf and basin cores, the small sampling interval reveals a pattern of subordinate peaks and troughs superimposed on what is assumed to be the older of the paired excursions. Although

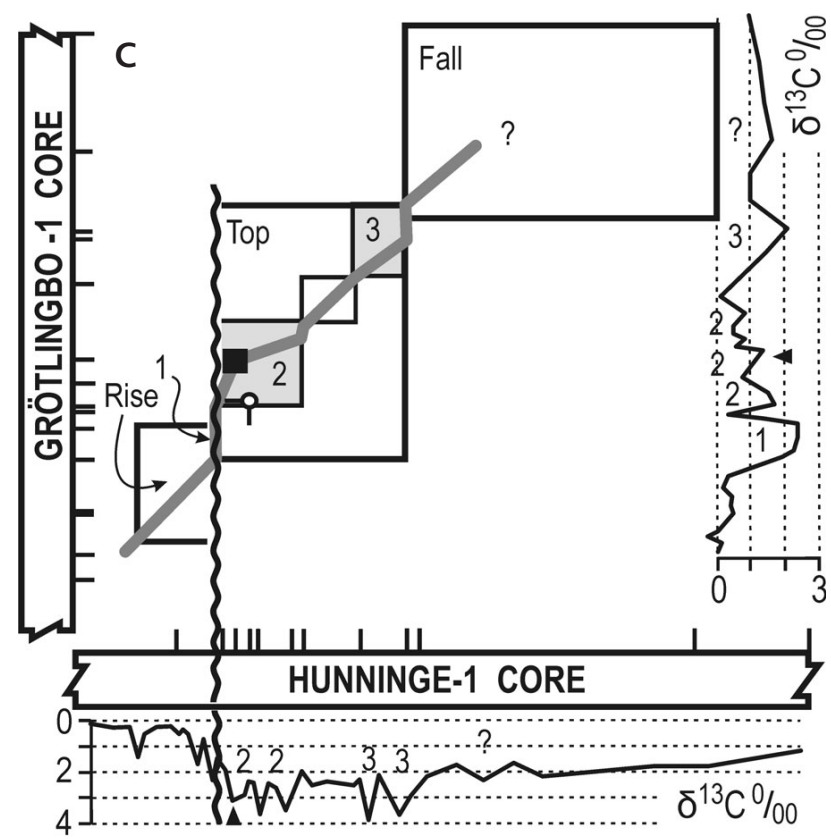

Figure 7. Three attempts to fit ordinal CONOP time-lines to subordinate isotopic fluctuations atop the older of the twin Homerian ("Mulde") carbon isotopic excursions in the Grötlingbo-1 and Hunninge-1 cores. - A - matches fluctuations without regard for the bentonite, which is forced out-of-bounds relative to the resulting uncertainty intervals on subordinate peaks (grey numbered boxes) and troughs (open boxes). - B - matches fluctuations in a manner that renders the bentonite correlation in-bounds. $-\mathrm{C}$ - attempts a closer match between the subordinate peaks at the level of the bentonite (black triangles), by reference to a hiatal surface (wavy line) that might crop the excursion record in the Hunninge core. Time-line details influenced by optimization of information from many other sections. All raw data from chart by Calner et al. (2003) who were wise not to portray the detailed correlation attempted for this demonstration.

several of these features would disappear with the removal of a single analysis, and although some similarity results merely from wider sampling intervals toward the top of the record in both cores, we can develop an example of data in conflict by noting tempting similarities of pattern in the raw data and imagining attempts to correlate them. An attempt that starts aligning peaks from the top down (Fig. 7A) fails to keep the bentonite in-bounds; the result cannot be accepted without challenging a traditional bentonite correlation. Aligning peaks from the bottom up (Fig. 7B) keeps the bentonite on the time-line. An attempt to match the subordinate peaks closest to the bentonite in each core (Fig. 7C) finds too few peaks below this level in the Hunninge core and must surmise that a hiatus known in shelf sections has cropped the record of fluctuations. Within this two-section projection of a small piece of the full Silurian data matrix, taxon range ends are insufficient resolve the options. A single shared taxon range-end (first-appearance of the graptolite Gothograptus nassa) serves only to confirm placement within the larger 


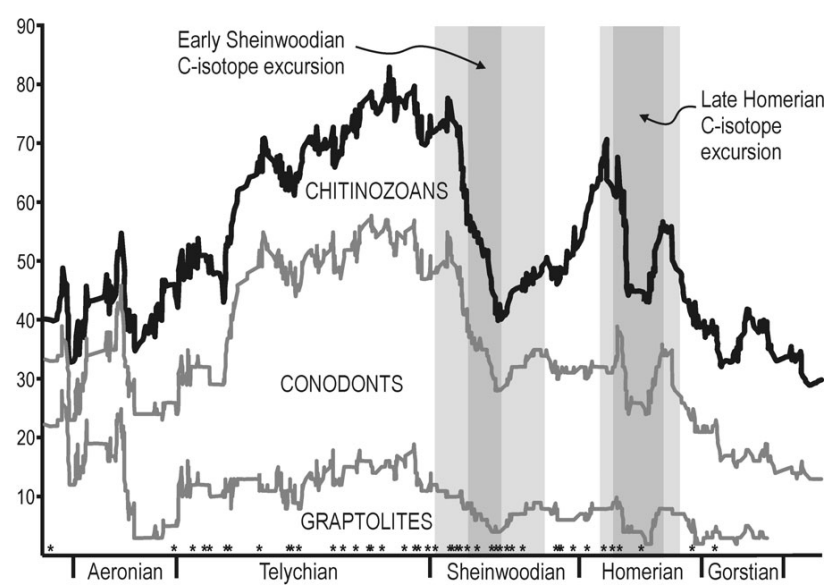

Figure 8. Part of high-resolution time series of taxon richness generated from 82-section CONOP time-line. Black line: raw, total, observed taxon richness from composite ranges; i.e. not corrected for uneven sampling (see Fig. 9). Grey lines: internal subdivision into richness components from three clades in the time-line. Vertical grey rectangles: composite uncertainty intervals for position of two carbon isotope excursions; dark grey: interval of peak values; light grey: rising and falling values adjacent to peak values. Asterisks: position of K-bentonites in composite time line. $\mathrm{X}$-axis: scaled (but uncalibrated) CONOP composite time-line from 82 Baltic Silurian sections and cores; scaling based on mean of rescaled separation of adjacent events in all sections (full explanation of scaling in Sadler et al. 2009). Stage boundaries located by first appearance of index graptolite taxa.

Homerian excursion. Figures $7 \mathrm{~B}$ and $\mathrm{C}$ have reached the limit of resolving power with the information at hand.

Notice that Fig. 7 shows uncertainty intervals for both the larger excursion plateau, and the smaller fluctuations within it. This ploy allows the optimization process to work with both finely and coarsely sampled sections. How might conflicted data like Fig. 7A arise in practice? It would likely be a consequence of compiling a large volume of information from many different sources. Discarding information is perilous too. Numerical algorithms have the advantage that they can efficiently seek out incompatibilities in huge data sets; they allow interpretation and quality control to proceed together.

\section{Connections between isotopic and biotic change}

Time-lines that incorporate geochemical excursions and range-end events for numerous marine taxa, rather than a few biozone boundaries, may be used to explore the co-evolution of ocean composition and biota from different clades at a resolution much finer than zones and stages (Sadler \& Cooper 2011). A highly resolved and unbinned taxon richness history can readily be recovered from time-lines as a running sum of origination events (+1) and extinction events $(-1)$. Estimates of taxon richness and

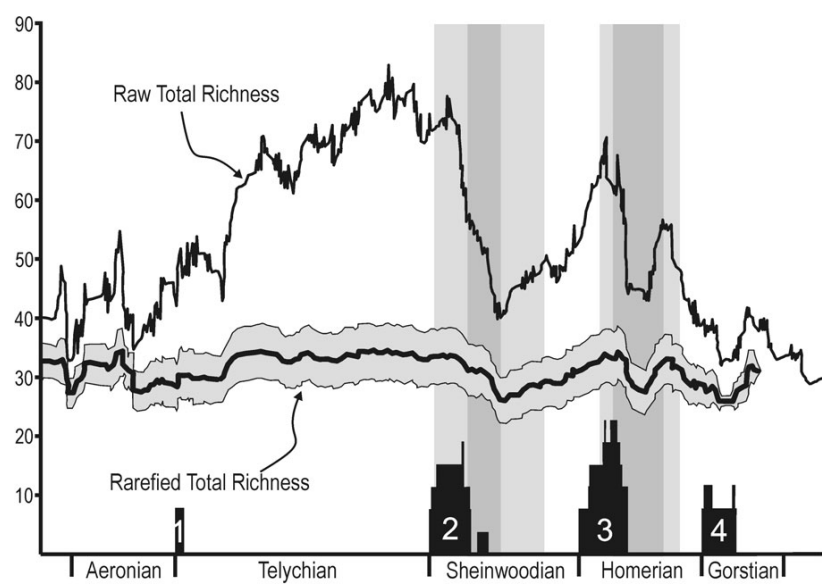

Figure 9. Taxon richness before and after rarefaction to a uniform sample size of 50 locally observed ranges. Grey band: $95 \%$ confidence interval on expected richness after rarefaction. Vertical grey rectangles: carbon isotope excursions as in Fig. 8. Numbered black histograms: position and number of locally observed ranges for four example taxa. 1 -Spirograptus guerichi; 2 -Cyrtograptus murchisoni; 3 -Cyrtograptus lundgreni; 4 -Neodiversograptus nilssoni. Time line as in Fig. 8.

mean longevity at every event level in the time-line are two of many standard outputs of the CONOP program. Because the isotope excursions have been part of the time-line optimization from the outset, their position in the time-line is evident without further recourse to calibration (Fig. 8). For the derived macro-evolutionary data, it is necessary to consider artifacts of uneven sampling (e.g. Foote 2000). The CONOP algorithms can map all unadjusted local ranges back into the time-line. This permits both taxonomic quality control and biogeographic analysis (Sadler 2010). Figure 9 shows the composite ranges of four example taxa in the form of histograms of the number of supporting local ranges as a function of position within the composite range. These histograms confirm that the ranges have continuous support and that abrupt first appearances may guide placements for stage boundaries in the time-line.

Knowledge of the location of every local range within the time-line also leads to a second richness curve that sums all local ranges rather than one composite range for each taxon. The result is a measure of sample size, from which CONOP can perform a standard rarefaction exercise to remove some influence of uneven sampling. Figure 9 indicates the expected taxon richness history for a uniform re-sampling level of 50 local ranges at each point in the time-line. An alternative CONOP option maps the span of each section into the time-line and reports per-section richness values.

Full analysis of Figs 8 and 9 is beyond the scope of this paper. Nevertheless, a familiar pattern is evident: the isotopic excursions correspond to intervals of rapid decline in diversity. Proper analysis requires consideration of the uneven sampling rate for different clades along the time-line 
(see Appendix for distribution of clades by section); i.e. more data collection or more corrective statistics. Better insight would derive from extending the geographic and temporal scope, but at the cost of even larger data volumes to handle. The Silurian of Baltica is still actually a rather small data set for CONOP to sequence; optimization takes a few hours on a laptop computer. The global graptoloid database (Sadler et al. 2011) now holds about 23,000 range-end observations for 2,259 taxa from 601 range charts; sequencing those data occupies a good laptop computer for 10-14 days. Each new isotope curve published for a section with a taxon range chart adds yet more data but also supplies constraints that can shorten the run time. Numerical optimization generates a wealth of diagnostic information for quality control of the input information, such as checking for disjunct taxon ranges and poorly constrained composite range-ends (Sadler 2010). After corrections are made - usually for taxonomic anomalies, less often for incompatible correlations of bentonites and isotope excursions - a better optimization run can begin. Although the logical rules of optimization are simple, it is not feasible to attempt such brute-force exercises manually.

\section{Summary}

As the volume of stratigraphic data grows, it becomes advantageous to transfer the logic of human expert correlation to computer algorithms that can manage tens of thousands of local and varied observations. In such exercises it is essential to encode as much time-stratigraphic information as possible but in a fashion that does not exaggerate the certainty or resolving power of that information. The form and clarity of local records of Silurian carbon isotope excursions varies with such factors as sample spacing, stratigraphic completeness, and sediment accumulation rate. Yet even loosely constrained isotopic excursions, favorably located, may have very beneficial effects on time correlation and the construction of palaeobiological time-lines. Accordingly, correlative segments and inflexion points in local isotope data are best incorporated as conservative uncertainty intervals. This is the opposite of Shaw's graphical treatment of taxon ranges. Each local range is likely to under-estimate the true taxon range and is, therefore, allowed to stretch when fitting all sections to the same composite time-line of range-end events. Uncertainty intervals on correlative parts of isotope excursions should be picked conservatively to match or over-estimate the true correlative intervals. While searching for the optimal sequence of stratigraphic events, sequencing algorithms may shrink the local uncertainty intervals as dictated by information from the most data-rich localities.

Implemented in this way, biostratigraphic and chemostratigraphic data complement one another. Taxon range information is more abundant but can be stretched to fit any time-line. "Shrink-to-fit" information (uncertainty intervals for stable isotope excursions) offers more constraint because shrinkage is an inherently more limited adjustment than stretching. Uncertainty intervals may shrink to a single point but no smaller; thus, their inclusion immediately reduces the number of feasible time-lines that must be considered in a search for the ones that best fit the biostratigraphic information. As the search converges on optimal sequences of events, parts of the time-line within the span of an isotope excursion or close to a fingerprinted bentonite will tend to be the best resolved in the sense that they show the fewest equally well-fit alternative sequences of events.

The biggest time-stratigraphic advantages accrue from stable isotope analyses of rocks from sections with well documented taxon range charts. Computer-assisted reconstruction of global palaeobiological change is progressing beyond the need to combine data into biozone- or stage-sized time bins. To keep pace with the resolving power of unbinned time-lines, it is desirable that stable isotope records be reported together with raw taxon ranges, or faunal lists, not merely the biozone boundaries estimated from them.

\section{Acknowledgements}

Clarity of an earlier draft was substantively improved by suggestions from Madis Rubel and Mark Kleffner, pioneers in the management of large Silurian data sets. Melanie Hopkins helped test the efficacy of uncertainty intervals. The development of CONOP was supported by grants EAR9219731, EAR9980372, OPP0338274, and EAR0518939 from the National Science Foundation and NNX10AR78G from NASA. This paper is a contribution to IGCP Project 591: The Early to Middle Paleozoic Revolution.

\section{References}

Alroy, J. 2004. Appearance event ordination: a new biochronologic method. Paleobiology 20, 191-207.

Bassett, M.G., Kaljo, D. \& Teller, L. 1989. The Baltic Region, 158-170. In Holland, C.M. \& Bassett, M.G. (eds) A global standard for the Silurian System. National Museums and Galeries of Wales, Geological Series 9.

Bergström, S.M., Toprak, F.O., Huff, W.D. \& Mundil, R. 2008. Implications of a new, biostratigraphically well-controlled, radio-isotopic age for the lower Telychian stage of the Llandovery series (Lower Silurian, Sweden). Episodes 31, 309-314.

BJERRESKov, M. 1975. Llandoverian and Wenlockian graptolites from Bornholm. Fossils and Strata 8, 1-94.

BjerReskov, M. 1986. Silurian graptolites from deep well Maglarp 1, Scania, Sweden. GFF 108(1), 1-12.

Brenchley, P. J., Carden, G. A., Hints, L., Kaljo, D., Marshall, J. D., Martma, T., Meidla, T. \& Nolvak, J. 
2003.High resolution stable isotope stratigraphy of Upper Ordovician sequences: constraints on the timing of bioevents and environmental changes associated with mass extinction and glaciation. Geological Society of America Bulletin 115(1), 89-104.

Calner, M. \& Jeppsson, L. 2003. Carbonate platform evolution and conodont stratigraphy during the middle Silurian Mulde event, Gotland, Sweden. Geological Magazine 140(2), 173-203. DOI 10.1017/S0016756802007070

Calner, M., KozŁowska, A., Masiak, M. \& Schmitz, B. 2006. A shoreline to deep basin correlation chart for the middle Silurian coupled extinction-stable isotopic event. GFF 128 , 79-84. DOI 10.1080/11035890601282079

Cody, R.D., Levy, R.H., Harwood, D.M. \& SAdLer, P.M. 2008. Thinking outside the zone: high-resolution quantitative diatom biochronology for the Antarctic Neogene. Palaeogeography, Palaeoclimatology, Palaeoecology 260, 92-121. DOI 10.1016/j.palaeo.2007.08.020

CRAMER, B.D. 2009. Application of integrated high-resolution biochemostratigraphy to Paleozoic chronostratigraphic correlation: recalibrating the Silurian system. 307 pp. Unpublished Ph.D. dissertation, The Ohio State University.

Cramer, B.D., Brett, C.E., Melchin, M.J., Männik, P., KlefFner, M.A., McLaughlin, P.I., Loydell, D.K., Munnecke, A., Jeppsson, L., Corradini, C., Brunton, F.R. \& Saltzman, M.R. 2011a. Revised correlation of Silurian Provincial Series of North America with global and regional chronostratigraphic units and $\delta^{13} \mathrm{C}_{\text {carb }}$ chemostratigraphy. Lethaia 44, 1700-1716.

Cramer, B.D., Condon, D.J., Soderlund, U., Marshall, C., Worton, G.J., Thomas, A.T. \& CALner, M. 2011b. U-Pb (zircon) age constraints on the timing and duration of Wenlock (Silurian) paleocommunity collapse and recovery during the Big Crisis. 39 pp. Written communication.

Cramer, B.D., Loydell, D.K., Samtleben, C., Munnecke, A., Kaljo, D., Männik, P., Martma, T., Jeppsson, L., KlefFner, M.A., Barrick, J.E., Johnson, C.A., EmSBo, P., JoAChimski, M.M., Bickerts, T. \& SAltzMAn, M.R. 2010. Testing the limits of Paleozoic chronostratigraphic correlation via high-resolution $(<500 \mathrm{k} . \mathrm{y}$.) integrated conodont, graptolite, and carbon isotope $\left(\delta^{13} \mathrm{C}_{\text {carb }}\right)$ biochemostratigraphy across the Llandovery-Wenlock (Silurian) boundary: Is a unified Phanerozoic time scale achievable? Geological Society of America Bulletin 122(9-10), 1700-1716. DOI 10.1130/B26602.1

DAhlquist, P. \& Bergström, S.M. 2005. The lowermost Silurian of Jamtland, central Sweden: conodont biostratigraphy, correlation and biofacies. Transactions of the Royal Society of Edinburgh: Earth Sciences 96, 1-19. DOI 10.1017/S0263593305000015

Foote, M. 2000. Origination and extinction components of taxonomic diversity: general problems, 74-102. In ERwIN, D.H. \& Wing, S.L. (eds) Deep Time: Paleobiology's Perspective. Paleobiology 26 (supplement).

Goldman, D., Bergström, S.M., Sheets, H.D. \& Pantle, C. 2011. A CONOP9 composite-taxon range-chart for Ordovician conodonts from Baltoscandia: a framework for biodiversity analyses. Cuadernos del Museo Geominero del Instituto Geológico y Minero de España 14, 179-188.

Gouwy, S. \& BulTynck, P. 2003. Conodont based graphic correlation of the Middle Devonian formations of the Ardenne
(Belgium): implications for stratigraphy and construction of a regional composite. Revista Española de Micropaleontologia 35(3), 315-344.

Grubb, B.J. \& Finney, S.C. 1995. Graphic correlation of Middle Ordovician graptolite-rich shales, southern Appalachians: successful application of a technique to inadequate stratigraphic sections, 151-158. In MANN, K.O. \& LANE, H.R. (eds) Graphic Correlation. SEPM Special Publication 53.

Hints, O., Nõlvak, J., Paluveer, L., \& Tammekänd, M. 2011. Conventional and CONOP9 approaches to biodiversity of Baltic Ordovician chitinozoans. Cuadernos del Museo Geominero del Instituto Geológico y Minero de España 14, 243-249.

Jeppsson, L. \& CALner, M. 2003. The Silurian Mulde event and a scenario for secundo-secundo events. Transactions of the Royal Society of Edinburgh: Earth Sciences 93, 135-154.

Kaljo, D., Hints, L., MänniK, P. \& NõlvaK, J. 2008. The succession of Hirnantian events based upon data from Baltica: brachiopods, chitinozoans, conodonts, and carbon isotopes. Estonian Journal of Earth Sciences 57(4), 197-218. DOI 10.3176/earth.2008.4.01

Kaljo, D. \& Martma, T. 2006. Application of carbon isotope stratigraphy to dating the Baltic Silurian rocks. GFF 128, 123-129. DOI 10.1080/11035890601282123

Kaminskas, D., PašKevičıus, J. \& RadZevičıus, S. 2006. Graptolite biostratigraphy and peculiarities of depositional environments during Late Llandovery and Wenlock according to geochemical data from Kurtuvenai-161 borehole (NW Lithuania). Geologija 53, 1-7.

Kemple, W.G., Sadler, P.M. \& Strauss, D.J. 1995. Extending graphic correlation to many dimensions: stratigraphic correlation as constrained optimization, 65-82. In MANN, K.O. \& Lane, H.R. (eds) Graphic Correlation. SEPM Special Publication 53.

KiIPli, T. \& Kallaste, T. 2006. Wenlock and uppermost Llandovery bentonites as stratigraphic markers in Estonia, Latvia, and Sweden. GFF 28, 139-146.

KiIPli, T., Kallaste, T. \& Nestor, V. 2010a. Composition and correlation of volcanic ash beds of Silurian age from the eastern Baltic. Geological Magazine 147(6), 895-909. DOI 10.1017/S0016756810000294

KiIPli, K., Kallaste, T., Nestor, V. \& Loydell, D.K. 2010b. Integrated Telychian (Silurian) K-bentonite chemostratigraphy and biostratigraphy in Estonia and Latvia. Lethaia 43, 32-44. DOI 10.1111/j.1502-3931.2009.00162.x

KiIPLI, T., KiIPLI, E. \& KaLJo, D. 2010c. Silurian sea level variations estimated using $\mathrm{SiO}_{2} / \mathrm{Al}_{2} \mathrm{O}_{3}$ and $\mathrm{K}_{2} \mathrm{O} / \mathrm{Al}_{2} \mathrm{O}_{3}$ ratios in the Priekule drill core section, Latvia. Bollettino della Società Paleontologica Italiana 49(1), 55-63.

Kimli, T., Radzevičius, S., Kallaste, T., Motuza, V., Jeppsson, L. \& WiCKSTRÖM, L.M. 2008. Wenlock bentonites in Lithuania and correlation with bentonites from sections in Estonia, Sweden, and Norway. GFF 30(4), 203-210.

KlefFner, M.A. \& Barrick, J.E. 2011. Telychian-early Sheinwoodian (early Silurian) conodont-, graptolite-, chitinozoanand event-based chronostratigraphy developed using the graphic correlation method. Memoirs of the Association of Australasian Palaeontologists 39, 191-210.

Koren', T. \& BJerreskov, M. 1997. Early Llandovery monograptids from Bornholm and the southern Urals: taxon- 
omy and evolution. Bulletin of the Geological Society of Denmark 44(1), 1-43.

Lisiecki, L.E. \& RAYMo, M.E. 2005. A Plio-Pleistocene stack of 57 globally distributed benthic $\delta^{18} \mathrm{O}$ records. Paleoceanography 20,1-17.

LOYDELl, D.K., Kaljo, D. \& MÄNNIK, P. 1998. Integrated biostratigraphy of the lower Silurian of the Ohesaare core, Saaremaa, Estonia. Geological Magazine 135, 69-783. DOI 10.1017/S0016756898001423

Loydell, D.K. \& MALETZ, J. 2004. The Silurian graptolite genera Strepograptus and Pseudostreptograptus. Journal of Systematic Palaeontology 2(2), 65-93.

DOI 10.1017/S1477201904001117

LOYdell, D.K., MänNiK, P. \& NestoR, V. 2003. Integrated biostratigraphy of the lower Silurian of the Aizpute-41 core, Latvia. Geological Magazine 140(2), 205-229. DOI 10.1017/S0016756802007264

LOYDELL, D.K. \& Nestor, V. 2005. Integrated graptolite and chitinozoan biostratigraphy of the upper Telychian (Llandovery, Silurian) of the Ventspils D-3 core, Latvia. Geological Magazine 142(4), 369-375.

DOI 10.1017/S0016756805000531

MACLEOD, N. \& SADLER, P.M. 1995. Estimating the line of correlation, 51-64. In ManN, K.O. \& Lane, H.R. (eds) Graphic Correlation. SEPM Special Publication 53.

Malkowski, K., Racki, G., Drygant, D. \& Szaniawski, H. 2007. Carbon isotope stratigraphy across the Silurian-Devonian transition in Podolia, Ukraine: evidence for a global biogeochemical perturbation. Geological Magazine 146(5), 674-689.

ManN, K.O. \& LANE, H.R. 1995. Graphic correlation: a powerful stratigraphic technique comes of age. SEPM Special Publication, 3-13. In ManN, K.O. \& LANE, H.R. (eds) Graphic Correlation. SEPM Special Publication 53.

Männik, P. 2007. An updated Telychian (Late Llandovery, Silurian) conodont zonation based on Baltic faunas. Lethaia 40, 45-60. DOI 10.1111/j.1502-3931.2006.00005.x

Männik, P. 2008. Conodont dating of some Telychian (Silurian) sections in Estonia. Estonian Journal of Earth Sciences 57(3), 156-159. DOI 10.3176/earth.2008.3.04

Männik, P., Bogolepova, O.K., Põldvere, A. \& Gubanov, A.P. 2009. New data on Ordovician-Silurian conodonts and stratigraphy for the Severnaya Zemlya archipelago, Russian Arctic. Geological Magazine 146(4), 497-516. DOI 10.1017/S0016756809006372

Martma, T., Brazauskas, A., Kaljo, D., Kaminskas, D. \& Musteikis, P. 2005. The Wenlock-Ludlow carbon trend in the Vidukle core, Lithuania. Geological Quarterly 49(2), 223-234.

NAKREM, H.A. 1986. Llandovery conodonts from the Olso region. Norway. Norsk Geologisk Tidsskrift 66, 121-133.

Nestor, V. 1990. Locality 7:4 Ohesaare Cliff, 175-178. In Kaljo, D. \& Nestor, H. (eds) Field Meeting Estonia 1990. Estonian Academy of Sciences, Institute of Geology.

Nestor, V. 2007. Chitinozoans in the Wenlock-Ludlow boundary beds of the East Baltic. Estonian Journal of Earth Sciences 56, $109-128$.

Nestor, H., Einasto, R., Nestor, V., Märss, T. \& Vitra, V. 2001. Description of the type section, cyclicity and correla- tion of the Riksu Formation (Wenlock, Estonia). Proceedings of the Estonian Academy of Sciences, Geology 50(3), 149-173.

Nestor, H. \& Nestor, V. 2002. Upper Llandovery to middle Wenlock (Silurian) lithostratigraphy and chitinozoan biostratigraphy in southwestern Estonia and northernmost Latvia. Proceedings of the Estonian Academy of Sciences, Geology 51(2), 67-87.

Nestor, H. \& Nestor, V. 2009. Upper Llandovery to Middle Wenlock (Silurian) lithostratigraphy and chitinozoan biostratigraphy in southwestern Estonia and northernmost Latvia. Proceedings of the Estonian Academy of Sciences, Geology 51(2), 67-87.

PAŠKEVIČIUS, J. 1976. On some new Llandoverian diplograptids of the Eastern Baltic, 140-151. In KaLjo, D. \& Koren', T.N. (eds) Graptolites in Stratigraphy. Academy of Sciences of Estonian SSR, Institute of Geology.

RADZEVIČIUS, S. 2006. Late Wenlock biostratigraphy and the Pristiograptus virbalensis group (Graptolintha) in Lithuania and the Holy Cross Mountains. Geological Quarterly 50(3), 333-344.

RadzevičIUs, S. 2007. The genus Pristiograptus in Wenlock of East Baltic and the Holy Cross Mountains. Dissertationes Geologicae Universitatis Tartuensis 20, 1-131.

Rubel, M. \& Einasto, R. 1990. Locality 6:1 Panga Cliff, 163-165. In KaLjo, D. \& Nestor, H. (eds) Field Meeting Estonia 1990. Estonian Academy of Sciences Institute of Geology.

Rubel, M., Hints, O., Männik, P., Meidla, T., Nestor, V., Sarv, L. \& SibUL, I. 2007. Lower Silurian biostratigraphy of the Viirelaid core, western Estonia. Estonian Journal of Earth Sciences 56(4), 193-204. DOI 10.3176/earth.2007.01

Rubel, M., Nestor, V., Harris, M.T., Sheehan, P.M., Ainsaar, L., MÄNnik, P. \& NõlvaK, J. 2006. A new high-resolution chitinozoan composite standard for the East Baltic lower Silurian succession based on numerical analysis. Geological Quarterly 50(3), 323-332.

SADLER, P.M. 2004. Quantitative biostratigraphy - achieving finer resolution in global correlation. Annual Reviews of Earth and Planetary Sciences 32, 187-213.

DOI 10.1146/annurev.earth.32.101802.120428

SADLER, P.M. 2006. Composite time lines: a means to leverage resolving power from radioisotopic dates and biostratigraphy, 145-170. In Olszewski, T. (ed.) Geochronology: Emerging Opportunities, Paleontological Society Papers 12.

SADLER, P.M. 2010. Brute-force biochronology: sequencing paleobiologic first- and last-appearance events by trial and error, 271-289. In Alroy, J. \& Hunt, G. (eds) Quantitative Methods in Paleobiology, Paleontological Society Papers 16.

Sadler, P.M. \& Cervato, C. 2011. Data and tools for geologic timelines and timescales, 145-165. In Keller, G.R. \& BARU, C. (eds) Geoinformatics. Cambridge University Press, Cambridge.

SADler, P.M. \& CoOPER, R.A. 2011. Graptoloid evolutionary rates: sharp contrast between Ordovician and Silurian. Cuadernos del Museo Geominero del Instituto Geológico y Minero de España 14, 499-503.

SAdler, P.M., CoOPER, R.A. \& Melchin, M.J. 2009. High-resolution, early Paleozoic (Ordovician-Silurian) time scales. Geological Society of America Bulletin 121(5/6), 887-906. DOI 10.1130/B26357.1 
SAdler, P.M., Cooper, R.A. \& Melchin, M.J. 2011. Sequencing the graptoloid clade: building a global diversity curve from local range charts, regional composites and global time-lines. Proceedings of the Yorkshire Geological Society 58, 329-343. DOI 10.1144/pygs.58.4.296

SAdLer, P.M., Kemple, W.G. \& Kooser, M.A. 2003. CONOP9 programs for solving the stratigraphic correlation and seriation problems as constrained optimization, 461-465 (and compact disc). In HARRIES, P.J. (ed.) High-resolution approaches in stratigraphic paleontology, Topics in Geobiology 21. Kluwer Academic Publishers, Dordrecht.

SADLER, P.M. \& SABADO, J.A. 2009. Automated correlation, seriation, and the treatment of biotic dissimilarity. Museum of Northern Arizona Bulletin 65, 21-35.

Shaw, A.B. 1964. Time in Stratigraphy. 365 pp. McGraw-Hill, New York.

SHAw, A.B. 1995. Early history of graphic correlation, 15-19. In Mann, K.O. \& LANE, H.R. (eds) Graphic Correlation. SEPM Special Publication 53.

Shen, S.Z., Crowley, J.L., Wang, Y., Bowring, S.A., Erwin, D.H., Sadler, P.M., CaO, C.Q., Rothman, D.H., Henderson, C.M., RameZani, J., Zhang, H., Shen, Y., Wang, X.D., Wang, W., Mu, L., LI, W.Z., TANG, Y.G., Liu, X.L., Liu, L.J.,
Zeng, Y., Jiang, Y.F. \& Jin, Y.G. 2011. Calibrating the End-Permian mass extinction. Science 334(6061), 1367-1372. DOI 10.1126/science. 1213454

Stouge, S. \& Rasmussen, J.A. 1996. Upper Ordovician conodonts from Bornholm and possible migration routes in the Palaeotethys ocean. Bulletin of the Geological Society of Denmark 43(1), 54-67.

SwEET, W.C. 2005. Graphical refinement of the conodont database: examples and a plea. Palaeontology 73, 135-141.

Tuuling, I. \& Floden, T. 2009. The Llandovery-lowermost Wenlock sequence in the Baltic Sea between Saaremaa and Gotland; subdivision, thickness and correlation, based on marine seismic studies. Marine Geology 267, 55-70. DOI 10.1016/j.margeo.2009.09.004

VIIRA, V. 1998. Silurian conodont biostratigraphy in the northern East Baltic. Bolletino della Società Paleontologica Italiana 37(2-3), 299-310.

VIIRA, V. 2008. Conodont biostratigraphy in the Middle-Upper Ordovician boundary beds of Estonia. Estonian Journal of Earth Sciences 57(1), 23-38. DOI 10.3176/earth.2008.1.03

ViIRA, V. \& EinAsto, R. 2003. Wenlock-Ludlow boundary beds and conodonts of Saaremaa Island, Estonia. Proceedings of the Estonian Academy of Sciences, Geology 52(4), 213-238. 


\section{Appendix}

Sections and Data Sources for BALTIC Correlation Exercise

\begin{tabular}{|c|c|c|c|c|c|}
\hline Section & $\mathrm{CH}$ & $\mathrm{CO}$ & GR & QQ & References \\
\hline Aizpute 41 link * & $\mathrm{x}$ & & & $\mathrm{x}$ & Loydell et al. (2003) \\
\hline Aizpute 41 lower & $\mathrm{x}$ & $\mathrm{x}$ & $\mathrm{x}$ & $\mathrm{x}$ & Loydell et al. (2003) \\
\hline Aizpute 41 upper & $\mathrm{x}$ & $\mathrm{x}$ & $\mathrm{x}$ & $\mathrm{x}$ & Loydell et al. (2003), Kiipli et al. (2010b) \\
\hline Anikaitse-Hulge & & $\mathrm{x}$ & & & Viira et al. (2003) \\
\hline Avaste & & $\mathrm{x}$ & & & Männik (2008) \\
\hline Bavnegård & & & $\mathrm{x}$ & & Bjerreskov (1975) \\
\hline Billegrav1 core & & & $\mathrm{x}$ & & Koren' et al. (1997) \\
\hline Conodont composite $*$ & & $\mathrm{x}$ & & & Cramer (2009) \\
\hline Djupvik 1-2 & & $\mathrm{x}$ & & & Calner et al. (2003) \\
\hline Dnistrove & & $\mathrm{x}$ & & $\mathrm{x}$ & Malkowski et al. (2007) \\
\hline Dubovskoye core & $\mathrm{x}$ & & & & Nestor et al. (2009) \\
\hline Edefors & & $\mathrm{x}$ & & & Dahlquist et al. (2005) \\
\hline Grötlingbo-1 core & & & $\mathrm{x}$ & $\mathrm{x}$ & Calner et al. (2006) \\
\hline Gussev-1 & $\mathrm{x}$ & & & & Nestor (2007) \\
\hline Hunninge 1 & & $\mathrm{x}$ & & & Calner et al. (2003) \\
\hline Hunninge core 1 & & & $\mathrm{x}$ & $\mathrm{x}$ & Cramer et al. (2011b), Calner et al. (2006) \\
\hline Ikla core lower & $\mathrm{x}$ & & & & Nestor et al. (2002) \\
\hline Ikla core link $*$ & $\mathrm{x}$ & & & & Nestor et al. (2002) \\
\hline Ikla core upper & $\mathrm{x}$ & & & & Nestor et al. (2002) \\
\hline Ireviken sect 3 & & $\mathrm{x}$ & $\mathrm{x}$ & $\mathrm{x}$ & Kiipli et al. (2006) \\
\hline Jadivere & & $\mathrm{x}$ & & & Männik (2008) \\
\hline Kaugatuma core & $\mathrm{x}$ & & & $\mathrm{x}$ & Kaljo et al. (2008), Brenchley et al. (2003) \\
\hline Kardla core & $\mathrm{x}$ & & & $\mathrm{x}$ & Kaljo et al. (2008), Brenchley et al. (2003) \\
\hline Kolka-54 & $\mathrm{x}$ & $\mathrm{x}$ & $\mathrm{x}$ & & Nestor (2007) \\
\hline Krasnaya Bay comp * & & $\mathrm{x}$ & & & Männik et al. (2009) \\
\hline Kunkojai-12 core & & & & $\mathrm{x}$ & Kiipli et al. (2008) \\
\hline Kurtuvenai-161 core & & & $\mathrm{x}$ & & Kaminskas et al. (2006) \\
\hline Laesa & & & $\mathrm{x}$ & & Bjerreskov (1975) \\
\hline Loggarve 2 & & $\mathrm{x}$ & & & Calner et al. (2003) \\
\hline Lygumai-47 core & & & $\mathrm{x}$ & & Kiipli et al. (2008) \\
\hline Maglarp1 well & & & $\mathrm{x}$ & & Bjerreskov (1986) \\
\hline Malmoya-Malmoykalven & & $\mathrm{x}$ & & & Nakrem (1986) \\
\hline Mehikoorma 421 core & & & $\mathrm{x}$ & $\mathrm{x}$ & Viira (2008) \\
\hline Mulde composite $*$ & & $\mathrm{x}$ & $\mathrm{x}$ & & Jeppsson et al. (2003) \\
\hline När-1 core & & $\mathrm{x}$ & $\mathrm{x}$ & $\mathrm{x}$ & Jeppsson et al. (2003) \\
\hline Ohesaare cliff & $\mathrm{x}$ & $\mathrm{x}$ & & & Nestor (1990) \\
\hline Ohesaare top & $\mathrm{x}$ & $\mathrm{x}$ & & $\mathrm{x}$ & Viira (1998) \\
\hline Ohesaare MT link * & & $\mathrm{x}$ & $\mathrm{x}$ & $\mathrm{x}$ & Viira (1998) \\
\hline Ohesaare middle & $\mathrm{x}$ & $\mathrm{x}$ & $\mathrm{x}$ & $\mathrm{x}$ & Loydell et al. (1998), Kiipli et al. (2010b) \\
\hline Ohesaare upper & $\mathrm{x}$ & $\mathrm{x}$ & & $\mathrm{x}$ & Viira (1998), Kiipli et al. (2008, 2010a) \\
\hline Øleå & & & $\mathrm{x}$ & & Bjerreskov (1975) \\
\hline Osmundsberg north & & & $\mathrm{x}$ & & Bergström et al. (2008) \\
\hline Osmundsberget & & & $\mathrm{x}$ & & Loydell et al. (2004) \\
\hline Paatsalu core & $\mathrm{x}$ & $\mathrm{x}$ & & $\mathrm{x}$ & Rubel et al. (2007) \\
\hline
\end{tabular}




\begin{tabular}{|c|c|c|c|c|c|}
\hline Section & $\mathrm{CH}$ & $\mathrm{CO}$ & GR & QQ & References \\
\hline Panga cliff & $\mathrm{x}$ & $\mathrm{x}$ & & & Rubel et al. (1990) \\
\hline Paroveja core & & & $\mathrm{x}$ & & Paškevičius (1976) \\
\hline Pavilosta & $\mathrm{x}$ & & $\mathrm{x}$ & & Nestor (2007), Nestor et al. (2009) \\
\hline Priekule core & & & $\mathrm{x}$ & $\mathrm{x}$ & Kiipli et al. (2010c) \\
\hline Pristio composite * & & & $\mathrm{x}$ & & Radzevičius (2007) \\
\hline Ragakre 1 & & $\mathrm{x}$ & & & Calner et al. (2003) \\
\hline Riekstini core & $\mathrm{x}$ & & & $\mathrm{x}$ & Brenchley et al. (2003) \\
\hline Riksu core & $\mathrm{x}$ & $\mathrm{x}$ & & & Nestor et al. (2001) \\
\hline Risebaek & & $\mathrm{x}$ & $\mathrm{x}$ & & Stouge et al. (1996) \\
\hline Rubel composite * & $\mathrm{x}$ & & & & Rubel et al. (2006) \\
\hline Ruhnu upper core & $\mathrm{x}$ & $\mathrm{x}$ & $\mathrm{x}$ & $\mathrm{x}$ & Kiipli et al. $(2008,2010 \mathrm{a}, \mathrm{b})$ \\
\hline Ruhnu1 core & $\mathrm{x}$ & & & $\mathrm{x}$ & Brenchley et al. (2003) \\
\hline Saastna lower & & $\mathrm{x}$ & & & Männik (2008) \\
\hline Saastna link * & & $\mathrm{x}$ & & & Männik (2008) \\
\hline Saastna upper & & $\mathrm{x}$ & & & Männik (2008) \\
\hline Sandvika & & $\mathrm{x}$ & & & Nakrem (1986) \\
\hline Siupyliai-69 core & & & $\mathrm{x}$ & $\mathrm{x}$ & Kiipli et al. (2008) \\
\hline Soeginina cliff & & $\mathrm{x}$ & & & Viira et al. (2003) \\
\hline Staicele core lower & $\mathrm{x}$ & & & & Nestor et al. (2002) \\
\hline Staicele core link * & $\mathrm{x}$ & & & & Nestor et al. (2002) \\
\hline Staicele core upper & $\mathrm{x}$ & & & & Nestor et al. (2002) \\
\hline Taagepera core & $\mathrm{x}$ & & & $\mathrm{x}$ & Brenchley et al. (2003) \\
\hline Tamme K-38 core & $\mathrm{x}$ & & & $\mathrm{x}$ & Brenchley et al. (2003) \\
\hline Ushakov River comp * & & $\mathrm{x}$ & & & Männik et al. (2009) \\
\hline Valga core & & & $\mathrm{x}$ & $\mathrm{x}$ & Kaljo et al. (2008) \\
\hline Valgu canal 1 & & $\mathrm{x}$ & & & Männik (2008) \\
\hline Valgu canal $2 \& 3$ & & $\mathrm{x}$ & & & Männik (2008) \\
\hline Velise-Korgekalde & & $\mathrm{x}$ & & & Männik (2008) \\
\hline Ventspils upper & $\mathrm{x}$ & $\mathrm{x}$ & $\mathrm{x}$ & $\mathrm{x}$ & Kaljo et al. (2006), Nestor (2007), Nestor et al. (2009) \\
\hline Ventspils lower & $\mathrm{x}$ & & $\mathrm{x}$ & & Loydell et al. (2005) \\
\hline Ventspils link * & $\mathrm{x}$ & & & $\mathrm{x}$ & Loydell et al. (2005), Bassett et al. (1989) \\
\hline Vidale-263 & $\mathrm{x}$ & & & $\mathrm{x}$ & Kiipli et al. (2010a) \\
\hline Vidukle-61 core & & $\mathrm{x}$ & $\mathrm{x}$ & $\mathrm{x}$ & Martma et al. (2005), Kiipli et al. (2008) \\
\hline Viirelaid core lower & $\mathrm{x}$ & $\mathrm{x}$ & & $\mathrm{x}$ & Rubel et al. (2007) \\
\hline Viirelaid core upper & $\mathrm{x}$ & $\mathrm{x}$ & & $\mathrm{x}$ & Rubel et al. (2007) \\
\hline Viirelaid hiatus * & $\mathrm{x}$ & $\mathrm{x}$ & & $\mathrm{x}$ & Rubel et al. (2007) \\
\hline Viki core & $\mathrm{x}$ & $\mathrm{x}$ & & $\mathrm{x}$ & Männik (2007), Kiipli et al. (2010b) \\
\hline Vilkauiskis-131 core & & & $\mathrm{x}$ & & Radzevičius (2006) \\
\hline
\end{tabular}

* "Pseudosection" with ordinal scale, but not true thickness

Abbreviations: $\mathrm{CH}=$ chitinozoan range data; $\mathrm{CO}=$ conodont range data; $\mathrm{GR}=$ graptolite range data; $\mathrm{QQ}=$ non biostratigraphic data (bentonites, isotope excursions, etc.) 